\title{
Characterization of Aspergillus species on Brazil nut from the Brazilian Amazonian region and development of a PCR assay for identification at the genus level
}

Glaucia EO Midorikawa', Maria de Lourdes M de Sousa², Otniel Freitas Silva², Jurema do Socorro A Dias ${ }^{3}$, Luis IB Kanzaki ${ }^{1}$, Rogerio E Hanada ${ }^{4}$, Renata MLC Mesquita ${ }^{4}$, Rivadalve C Gonçalves ${ }^{5}$, Virginia S Alvares ${ }^{5}$, Daniela MC Bittencourt ${ }^{6}$ and Robert NG Miller ${ }^{1 *}$

\begin{abstract}
Background: Brazil nut is a protein-rich extractivist tree crop in the Amazon region. Fungal contamination of shells and kernel material frequently includes the presence of aflatoxigenic Aspergillus species from the section Flavi. Aflatoxins are polyketide secondary metabolites, which are hepatotoxic carcinogens in mammals. The objectives of this study were to identify Aspergillus species occurring on Brazil nut grown in different states in the Brazilian Amazon region and develop a specific PCR method for collective identification of member species of the genus Aspergillus.

Results: Polyphasic identification of 137 Aspergillus strains isolated from Brazil nut shell material from cooperatives across the Brazilian Amazon states of Acre, Amapá and Amazonas revealed five species, with Aspergillus section Flavi species A. nomius and A. flavus the most abundant. PCR primers ASP_GEN_MTSSU_F1 and ASP_GEN_MTSSU_R1 were designed for the genus Aspergillus, targeting a portion of the mitochondrial small subunit ribosomal RNA gene. Primer specificity was validated through both electronic PCR against target gene sequences at Genbank and in PCR reactions against DNA from Aspergillus species and other fungal genera common on Brazil nut. Collective differentiation of the observed section Flavi species A. flavus, A. nomius and A. tamarii from other Aspergillus species was possible on the basis of RFLP polymorphism.
\end{abstract}

Conclusions: Given the abundance of Aspergillus section Flavi species A. nomius and A. flavus observed on Brazil nut, and associated risk of mycotoxin accumulation, simple identification methods for such mycotoxigenic species are of importance for Hazard Analysis Critical Control Point system implementation. The assay for the genus Aspergillus represents progress towards specific PCR identification and detection of mycotoxigenic species.

Keywords: Aspergillus section Flavi, Mycotoxin, Mitochondrial small subunit ribosomal RNA gene, PCR-RFLP

\footnotetext{
* Correspondence: robertmiller@unb.br

'Departamento de Biologia Celular, Instituto de Ciências Biológicas,

Universidade de Brasília, Campus Universitário Darcy Ribeiro, CEP 70.910-900

Brasília D.F., Brazil

Full list of author information is available at the end of the article
}

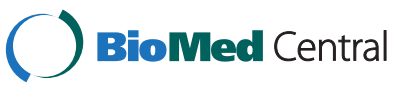

(c) 2014 Midorikawa et al.; licensee BioMed Central Ltd. This is an Open Access article distributed under the terms of the Creative Commons Attribution License (http://creativecommons.org/licenses/by/2.0), which permits unrestricted use, distribution, and reproduction in any medium, provided the original work is properly credited. The Creative Commons Public Domain Dedication waiver (http://creativecommons.org/publicdomain/zero/1.0/) applies to the data made available in this article, unless otherwise stated. 


\section{Background}

Aflatoxins (AF) are polyketide family secondary metabolites produced by several members of the fungal genus Aspergillus, section Flavi. Considered amongst the most dangerous natural hepatotoxic carcinogens in mammals [1], consumption of foodstuffs contaminated with these extrolites can be a cause of mortality and reduced productivity in higher vertebrates. Within this family, AFB1, B2, G1 and G2 cause most concern, given their abundance and toxicity [2]. The mycotoxin cyclopiazonic acid (CPA) [3] can also be produced by aspergilli. This toxic indole tatramic acid is associated with damage to liver, heart and kidneys [4].

The taxonomy of the genus Aspergillus is complex, with overlapping morphological characteristics and biochemical properties between species, as well as intraspecific polymorphism [5,6]. Aspergillus section Flavi comprises over 20 member species, based on polyphasic approaches for species delimitation that consider morphological, molecular and extrolite data [7-10]. A number of species within the section are aflatoxigenic, including the widely distributed species $A$. flavus, $A$. parasiticus and $A$. nomius, together with $A$. arachidicola, $A$. bombycis, A. minisclerotigenes, $A$. parvisclerotigenus, A. pseudocaelatus, A. pseudonomius and A. pseudotamarii, ([7] and references therein), A. novoparasiticus [8], A. mottae, A. sergii and A. transmontanensis [9].

Brazil nut (Bertholletia excelsa Humb. \& Bompl.) is a protein-rich oily nut, which, as an extractivist tree crop, provides employment to communities in the Amazon region. Currently, Bolivia and Brazil are the world's largest producers, with annual production in excess of 40 thousand tons [11]. Aflatoxin contamination negatively affects exports, with maximum tolerable limits imposed by the European Commission of $8.0 \mu \mathrm{g} / \mathrm{kg}$ and $5.0 \mu \mathrm{g} / \mathrm{kg}$ for AFB1, for unshelled and shelled nuts, respectively, and $15.0 \mu \mathrm{g} / \mathrm{kg}$ and $10.0 \mu \mathrm{g} / \mathrm{kg}$ for total aflatoxins (AFB1, AFB2, AFG1 and AFG2). A. flavus and A. nomius are common aflatoxin producers on Brazil nut $[12,13]$, with less frequent isolation of aflatoxigenic species $A$. arachidicola, A. bombycis, A. parasiticus and A. pseudotamarii $[12,14,15]$. Non aflatoxigenic species include Flavi section members $A$. caelatus and $A$. tamarii, as well as aspergilli which are not classified in the section, such as $A$. versicolor and A. sydowii [12].

Given that morphological characters can be insufficient for distinguishing certain species belonging to section Flavi, numerous molecular-based approaches have been developed. These have included analysis of rDNA ITS and aflRaflJ intergenic spacers for differentiation of $A$. flavus and $A$. parasiticus [16,17], as well as AFLP and SNP analysis for differentiation of A. flavus/A. oryzae, A. parasiticus/A. sojae, $A$. tamarii and $A$. nomius $[18,19]$. Sequence-based approaches include analysis of rDNA ITS and $28 \mathrm{~S}$ rRNA variable regions $[20,21]$, together with calmodulin and $\beta$-tubulin gene regions $[7,22,23]$. Variability in the latter two genes can be appropriate for resolving closely related Aspergillus species [24]. Molecular identification of nine species of section Flavi was recently described, based upon amplification of aflT and aflR genes and rDNA ITS regions, genomic DNA SmaI-derived RFLPs, and RAPD fingerprinting [25]. Specific detection of section Flavi species in contaminated material has been described using both PCR e.g. [26] and loop-mediated isothermal amplification [27].

Hazard Analysis Critical Control Point (HACCP) methods are employed to reduce the risk of contamination of foods with microbial pathogens, toxins or allergens [28]. When setting up HACCP concepts, species identification is necessary for determining critical control points (CCPs) in the field, storage or transport. In this context, the objectives of this study were to identify Aspergillus species occurring on Brazil nut from different states in the Brazilian Amazon region on the basis of morphological, molecular and extrolite data, followed by the development of a PCR method for collective identification of member species of the genus Aspergillus.

\section{Results}

Identification and abundance of Aspergillus species

Polyphasic identification of all 137 Aspergillus strains isolated from Brazil nut shell material collected from cooperatives across the Brazilian Amazon region (states of Acre, Amapá and Amazonas) revealed the presence of five species, with three belonging to Aspergillus section Flavi. Blastn-derived analyses against Aspergillus species sequences deposited in Genbank for ex-type strains revealed similarities of between 99 and 100\% for rDNA ITS, $\beta$-tubulin and calmodulin sequences.

Qualitative analysis of mycotoxigenic potential in representative strains of the aflatoxigenic species isolated from different regions revealed, for A. flavus, AFB1, AFB2 and CPA production in 11 evaluated strains, and AFB1 and CPA production for a further five strains. From a total of seven examined strains of $A$. nomius, five produced AFB1, AFB2, AFG1 and AFG2, one produced B1 and G1, and one produced B1, G1 and G2. CPA was not detected in A. nomius.

When considering totals for each species from all growing areas analysed, aflatoxigenic species $A$. nomius and A. flavus were the most abundant, representing 43.1 and $42.3 \%$ of all isolated aspergilli, respectively (Table 1). The non aflatoxigenic species $A$. tamarii was observed at a lower overall frequency (13.13\%). Aspergillus species which do not belong to section Flavi were also isolated, with one isolate of A. fumigatus from Amapá and one isolate of A. niger from Amazonas. When comparing A. nomius and A. flavus, although similar numbers of strains were identified in total, numbers varied considerably across regions, 
Table 1 Frequency of Aspergillus species from Brazil nut material across the Brazilian Amazon region

\begin{tabular}{|c|c|c|c|c|c|}
\hline \multirow[t]{2}{*}{ State } & \multicolumn{5}{|c|}{ Number of strains isolated from Brazil nut material } \\
\hline & A. nomius & A. flavus & A. fumigatus & A. tamarii & A. niger \\
\hline Acre & $1(5.3)^{*}$ & $18(94.7)$ & 0 & 0 & 0 \\
\hline Amapá & $20(95.2)$ & 0 & $1(4.8)$ & 0 & 0 \\
\hline \multicolumn{6}{|l|}{ Amazonas } \\
\hline Coari & $5(83.3)$ & 0 & 0 & $1(16.7)$ & 0 \\
\hline Humaitá & $7(14.3)$ & $40(81.6)$ & 0 & $1(2.05)$ & $1(2.05)$ \\
\hline Itacoatiara & $19(90.5)$ & 0 & 0 & $2(9.5)$ & 0 \\
\hline Manicoré & 7 (33.33) & 0 & 0 & $14(66.66)$ & 0 \\
\hline Total & $59(43.1)$ & $58(42.3)$ & $1(0.73)$ & $18(13.13)$ & $1(0.73)$ \\
\hline
\end{tabular}

*Values in parentheses indicate percentages for each species for each geographical region.

with $A$. nomius more frequent in samples from Amapá, Coari (Amazonas), Itacoatiara (Amazonas) and Manicoré (Amazonas), and A. flavus more common in contaminated material from Acre and Humaitá (Amazonas).

\section{MtDNA primer development for genus}

Following sequence alignment of a portion of the mtDNA SSU rRNA gene from Genbank-derived sequences for all available Aspergillus species, specific primers ASP_GEN_MTSSU_F1 (5'-GCCATATTACTCTTGAGGTGGAA-3') and ASP_GEN_MTSSU_R1 (5'-CCGAAAGGCTGAACCAGTAA-3') were designed for amplification of a $480 \mathrm{bp}$ PCR product specific for the genus (Figure 1). In silico analysis of the specificity of the primer pair was based upon electronic PCR against mtDNA SSU rDNA gene sequences available at Genbank for the genus Aspergillus and fungi from additional genera previously reported on Brazil nut [29]. Positive nucleotide BLAST search results with $0 \%$ mismatch were observed against target mtDNA SSU rRNA from all available Aspergillus species, as well as teleomorphs from the genera Chaetosartorya, Emericella, Eurotium and Petromyces. For all additional fungal genera documented on this host, primer annealing sites were absent in sequences. Wider testing across all deposited fungal mitochondrial DNA sequences in Genbank revealed primer target sequences in Mycena sp., Monascus purpureus and Leiothecium ellipsoideum, although expected amplicon sizes were at least 41 bp shorter than that expected for the genus Aspergillus.

When validating specificity of the primer pair against fungal DNA, a PCR product of the expected size was amplified only from members of the genus Aspergillus, with no amplification observed for other fungal genera associated with $B$. excelsa (Figure 2). An IAC was included for co-amplification in each sample to prevent false negative results which could potentially be caused by PCR inhibitors [30]. An IAC concentration of $10 \mathrm{pg}$ was identified as optimum for simultaneous amplification of the $480 \mathrm{bp}$ specific Aspergillus amplicon and the
330 bp IAC with primers ASP_GEN_MTSSU_F1, ASP_GEN_MTSSU_R1 and M13 reverse. Validation of the specific primers for detection of Aspergillus DNA directly from naturally contaminated samples showed that amplification of the genus-specific PCR product was possible from a minimum of $10 \mathrm{ng}$ of total DNA extracted from Brazil nut material.

\section{RFLP analysis}

Restriction maps for the specific mtDNA SSU rRNA amplicon for the genus were compared across the Aspergillus species isolated from Brazil nut. Minor nucleotide sequence differences were detected, with the restriction endonuclease DraI appropriate for differentiating the isolated Aspergillus section Flavi members from other species in the genus also encountered on Brazil nut. According to the restriction maps for the five isolated Aspergillus species in this study, two conserved restriction sites are present for this enzyme in the target amplicon region for the isolated Aspergillus section Flavi members A. flavus, A. nomius and A. tamarii, which should result in PCR product cleavage into fragments of 30, 170 and $237 \mathrm{bp}$. Predicted restriction digest patterns were compared in mtDNA SSU rRNA sequences available in Genbank for section Flavi species A. parasiticus, $A$. oryzae and $A$. sojae, together with the A. flavus synonyms A. kambarensis, A. subolivaceus and A. thomii [7]), and for the $A$. tamarii synonym $A$. terricola [7]). These sequences showed the same two conserved DraI restriction sites, in contrast to distinct RFLP profiles observed in sequences for Aspergillus species not belonging to section Flavi (Additional file 1), as well as in the Aspergillus teleomorphs and non-target genera Mycena, Monascus and Leiothecium.

In order to validate the restriction mapping data, PCR RFLP analysis was conducted on PCR-amplified specific mtDNA SSU rRNA amplicons across the different Aspergillus species isolated. PCR-RFLPs with DraI confirmed differentiation of these three section Flavi members from 


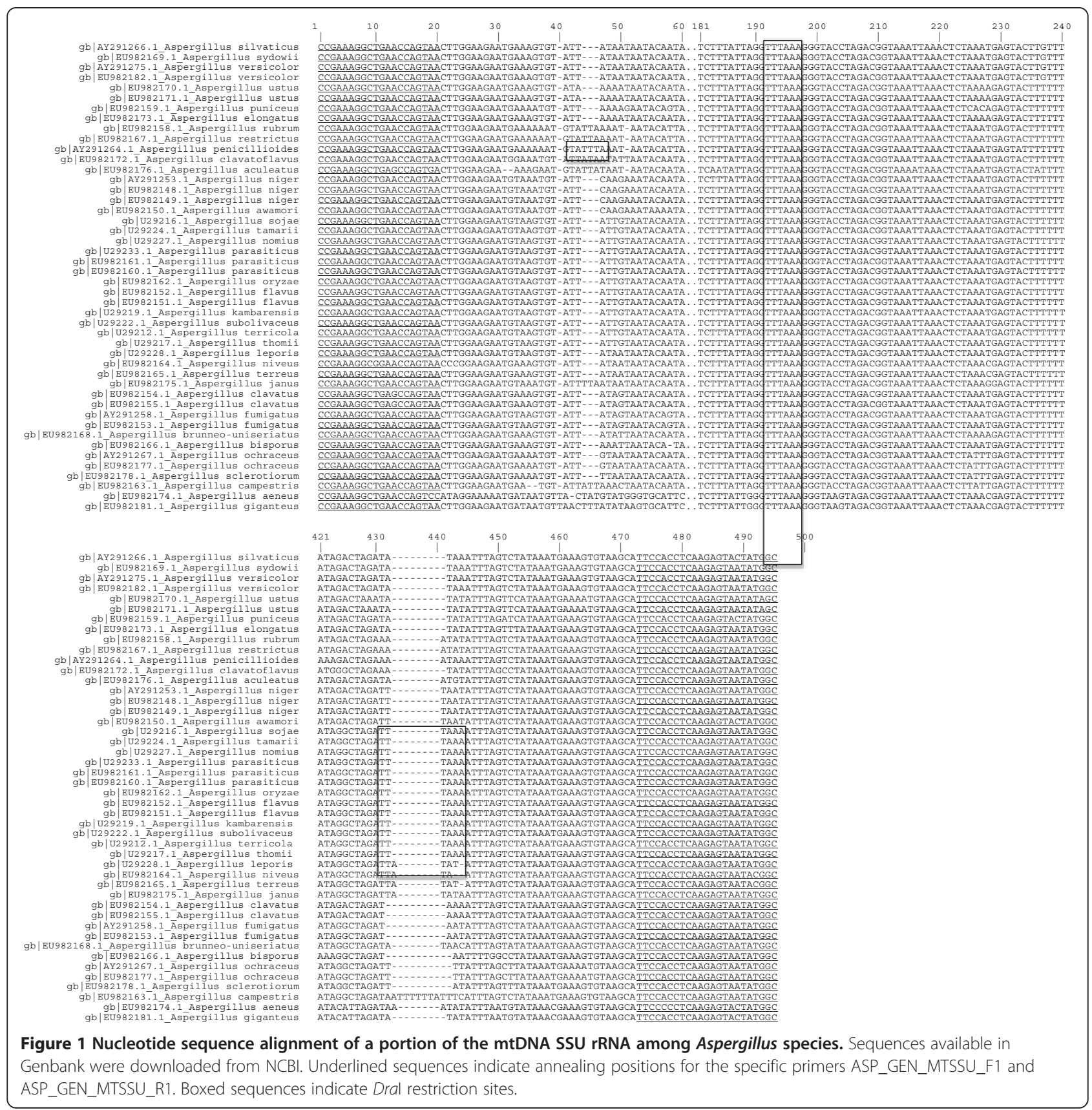

the other Aspergillus species, with digest patterns in agreement with in silico data (Figure 3).

\section{Discussion}

Morphology-based methods for identification of species of the genus Aspergillus can be unreliable as a result of both intraspecific similarities and differences [16]. In this present study, identification of Aspergillus species on Brazil nut from different states in the Brazilian Amazon region was conducted according to Samson and Varga [6] and Baquião et al. [14], through morphological and molecular characterization, together with extrolite profile (aflatoxins and CPA). As observed in previous studies for section Flavi [24,31], species identifications based upon analyses of rDNA ITS, $\beta$-tubulin and calmodulin gene sequence identities against sequences for ex-type strains available through the NCBI nucleotide nr database provided results in agreement with morphology-based identification and extrolite production.

The frequency we observed of aflatoxigenic Aspergillus section Flavi species from Brazil nut shell material confirmed recent reports that $A$. nomius and $A$. flavus are abundant species on Brazil nut across production areas in the Brazilian Amazonian region [14,32]. In our study, 


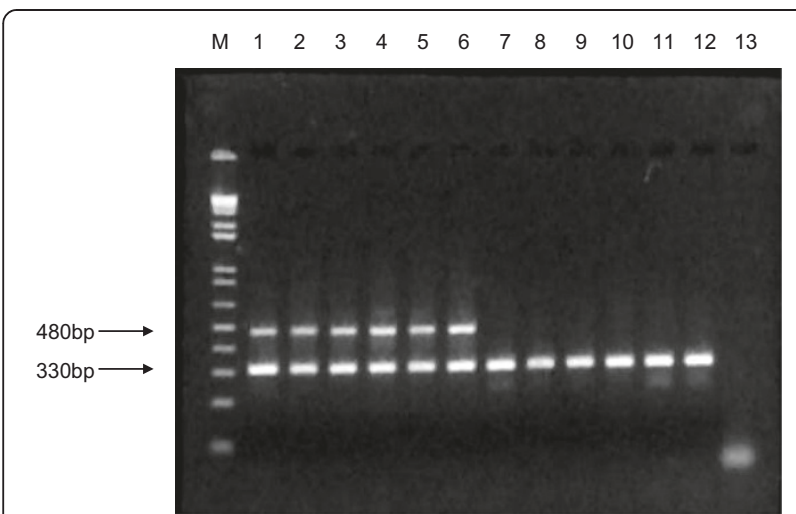

Figure 2 PCR amplification of a specific mtDNA SSU rRNA amplicon for species members of the genus Aspergillus using primers ASP_GEN_MTSSU_F1 and ASP_GEN_MTSSU_R1, together with co-amplification of an internal amplification control. M: 1 Kb plus DNA ladder; 1-2: Aspergillus flavus; 3: Aspergillus nomius; 4: Aspergillus tamarii; 5: Aspergillus fumigatus; 6: Aspergillus niger; 7-8: Fusarium solani f. sp. glycines; 9: Fusarium solani; 10: Penicillium citrinum; 11: Trichoderma harzianum; 12: Cladosporium cladosporioides; 13: negative control.

these two species represented over $85 \%$ of all Aspergillus species isolated. Qualitative analysis of mycotoxin production in strains of the mycotoxigenic species representative of the different states of origin supported the identifications, with $A$. flavus strains producing AFB and CPA, and A. nomius producing AFB and AFG, without CPA production. The extrolite profiles are in agreement with expected chemical characterization data for these member species in the section $[16,33]$.

Given the documented widespread occurrence of both $A$. flavus and $A$. nomius on Brazil nut, together with the known capacity to produce mycotoxins AFB and CPA,

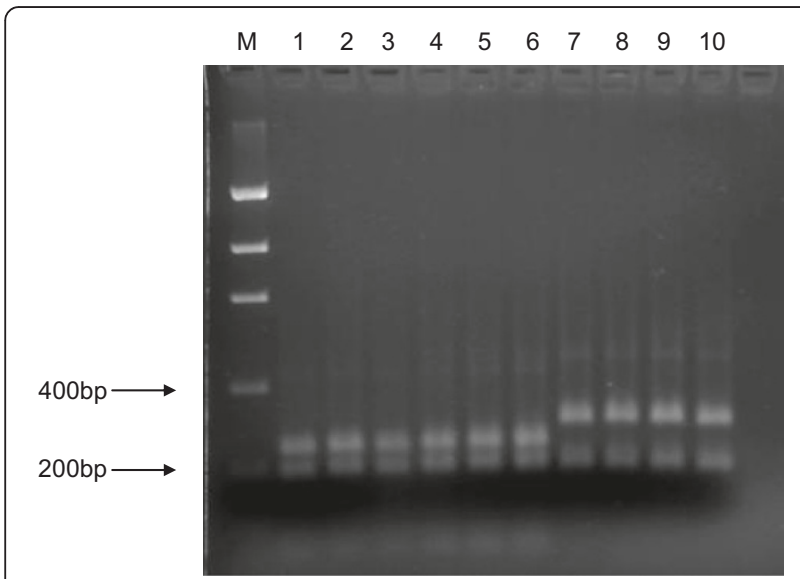

Figure 3 Dral restriction digest profiles of the specific mtDNA SSU rRNA amplicon for differentiation of Aspergillus section Flavi species members from other aspergilli. M: Low DNA Mass Ladder; 1-3: Aspergillus flavus; 4-5: Aspergillus nomius; 6: Aspergillus tamarii; 7-8: Aspergillus fumigatus; 9-10: Aspergillus niger. and AFB and AFG, respectively, the presence of these species on husk materials represents a threat to safe production of Brazil nut. As the section Flavi species $A$. tamarii and $A$. fumigatus are also documented producers of CPA [34,35], the occurrence of these species on Brazil nut highlights the need for regulations which also consider this mycotoxin.

PCR-based molecular diagnosis of microorganisms offers specificity and sensitivity appropriate for early detection, appropriate for both HACCP purposes [36] and implementation of countermeasures for control of microbial contamination. As Brazil nut is an extractivist crop, with aflatoxigenic species occurring throughout the production chain $[32,37]$, safe production is dependent upon identification of CCPs and subsequent implementation of detection methods at these points. The mitochondrial genome is an attractive molecule for application in fungal taxonomy and systematics, with a rapid rate of evolution and limited genetic recombination [38,39]. For Aspergillus, both specific and intraspecific level comparisons have been described [40,41]. Considering the high copy number per cell, mitochondrial DNA (mtDNA) is also easily amplifiable by PCR and appropriate for characterization through RFLP analysis. In the current study, analysis of the mtDNA SSU rRNA gene region enabled the design of a genus-specific primer pair for amplification of a $480 \mathrm{bp}$ PCR product in Aspergillus. Specific amplification was possible using DNA extracted from pure cultures, as well as from naturally contaminated Brazil nut samples. Together with the developed IAC, this PCR-based method has potential for inclusion in the setup of HACCP concepts. Many attempts with genetic markers for differentiation of section members at the interspecific level have not provided sufficient resolution for detection of small differences across the fungal genomes. In the case of the closely related species $A$. flavus and $A$. oryzae, minor differences across the genome can only be revealed by detecting differences across numerous loci, such as digestion of total DNA with restriction endonucleases [42] or aflatoxin biosynthetic pathway gene interspecific polymorphism [43]. Similarly, the closely related species $A$. parasiticus and $A$. sojae can only be distinguished using genetic markers such as RAPD [44]. Our approach based upon the use of genus specific primers for mtDNA SSU rDNA followed by RFLPs appeared to resolve phylogenetically distant species, with the three section Flavi member species encountered in this study all displaying a single RFLP profile. In silico analysis of restriction sites in the target mtDNA SSU rDNA sequence for all Aspergillus species available in Genbank supported the observed polymorphisms delimiting in a group specific manner, separating section Flavi species from other species not classified in the section. Further investigation of this polymorphism is warranted across all member species of the section. 


\section{Conclusions}

In conclusion, five species of Aspergillus were identified on Brazil nut material from cooperatives across states in the Brazilian Amazon region, with the aflatoxigenic Aspergillus section Flavi species $A$. nomius and $A$. flavus the most abundant. A specific PCR-based method for identification at the genus level was developed, which also enabled collective differentiation of the observed section Flavi species A. flavus, A. nomius and A. tamarii from other Aspergillus species, on the basis of RFLP polymorphism. Given the widespread distribution of Aspergillus section Flavi species and associated risk of food contamination due to mycotoxin accumulation, simple molecular methods to aid identification of mycotoxigenic species are of importance in identification of CCPs at the point of production and storage, from which appropriate management practices can be developed.

\section{Methods}

\section{Fungal isolation}

Strains belonging to the genus Aspergillus were isolated from $3 \mathrm{~L}$ samples of Brazil nut collected from cooperatives in growing areas in eastern and western regions of the Brazilian Amazon (Amapá, Amazonas and Acre states). A total of three localities were sampled per state. Isolation into pure culture from shell tissues was performed according to Freire et al. [45]. Single spore cultures were used throughout the study, with all strains preserved both in $20 \%$ glycerol at $-80^{\circ} \mathrm{C}$ and on silica gel at $4^{\circ} \mathrm{C}$. Strains were identified to species level based on macroscopic colony morphology and conidial morphology, extrolite production, and sequence data identities for rDNA ITS, $\beta$-tubulin and calmodulin gene regions, as described previously $[7,32,46]$. A representative isolate for each haplotype of each identified Aspergillus species was preserved as a single spore culture and deposited in the reference mycological culture collection at the Department of Phytopathology, University of Brasilia.

\section{Determination of aflatoxins and cyclopiazonic acid}

Analysis of mycotoxigenic potential of a number of Aspergillus section Flavi strains representative of each state was conducted under permissive conditions according to Schmidt-Heydt et al. [47], following growth at $25^{\circ} \mathrm{C}$ for 7 days on YES medium $(20 \mathrm{~g} / \mathrm{L}$ yeast extract, $150 \mathrm{~g} / \mathrm{L}$ sucrose, $0,5 \mathrm{~g} / \mathrm{L} \mathrm{MgSO}_{4} 5 \mathrm{H}_{2} \mathrm{O}, 0.1 \mathrm{~g}$ de $\mathrm{ZnSO}_{4}, 0.05 \mathrm{~g}$ $\mathrm{CuSO} 4,15 \mathrm{~g} / \mathrm{L}$ agar), with water activity adjusted to 0.99 , using a glycerol/water mixture of $108 \mathrm{~mL}$ glycerol per litre. Aflatoxin and cyclopiazonic acid standards were acquired from Sigma-Aldrich (Saint Louis, MO, USA), with liquid chromatography grade solvents from Merck (Darmstadt, Germany). For each fungal colony, mycotoxins from the entire content for each colonized plate were extracted under shaking conditions in $10 \mathrm{~mL}$ methanol at room temperature for $60 \mathrm{~min}$. Following simple filtration using Whatman No. 1 filter papers, $500 \mu \mathrm{L}$ of type 1 purified $\mathrm{H}_{2} \mathrm{O}$ was added to $500 \mu \mathrm{L}$ of supernatant and filtered through a $0.22 \mu \mathrm{m}$ teflon membrane. A total of $10 \mu \mathrm{L}$ of filtrate were diluted with $990 \mu \mathrm{L}$ of acetonitrile:water $(20: 80, \mathrm{v} / \mathrm{v})$. The filtrate $(10 \mu \mathrm{L})$ was then subjected to UPLC/MS/MS analysis. Calibration curves were prepared for each mycotoxin standard using six concentrations: AFB1 0.25, 0.5, 1.0, 5.0, 7.5 and $10.0 \mathrm{ng} / \mathrm{mL}$; AFB2 0.06, $0.125,0.25,1.25,1.875,2.50$; AFG1 0.25, 0.50, 1.0, 5.0, 7.6, $10.0 \mathrm{ng} / \mathrm{mL}$; AFG2 0.06, 0.125, 0.25, 1.25, 1.875, 2.50; ACP $5,10,20,100,150,200 \mathrm{ng} / \mathrm{mL}$ ). The $\mathrm{R} 2$ varied between 0.94 and 0.994 , depending on the toxin. The quantification limits were $0.1 \mathrm{ng} / \mathrm{mL}$ for AFB1, 0.04 for AFB2, 0.10 for AFG1, 0.02 for AFG2 and 0.2 for CPA. Analyses were performed on an ACQUITY UPLC ${ }^{\mathrm{m}}$ separation system coupled with a Quattro Premier ${ }^{\text {Tix }}$ XE tandem quadrupole mass spectrometer (Waters, Manchester, UK). The software MassLynx version 4.1 with application manager software QuanLynx (Waters) was employed for instrument control and data analysis. Chromatographic separation of toxins was conducted using an ACQUITY UPLC BEH C18 $(1.7 \mu \mathrm{m}, 2.1 \times 100 \mathrm{~mm}$; Waters $)$. Elution was performed using the gradient: mobile phase $\mathrm{A}\left(\mathrm{H}_{2} \mathrm{O}+0.2 \%\right.$ formic acid) and mobile phase $\mathrm{B}$ (acetonitrile $+0.2 \%$ formic acid): $0-1 \min (10 \% \mathrm{~B}) ; 10 \mathrm{~min}(50 \% \mathrm{~B}) ; 10.5 \mathrm{~min}$ $(85 \% \mathrm{~B}) ; 11 \mathrm{~min}(10 \% \mathrm{~B})$; and $12 \mathrm{~min}(10 \% \mathrm{~B})$. Flow rate was set at $0.4 \mathrm{~mL} / \mathrm{min}$, with a column temperature of $40^{\circ} \mathrm{C}$ and total run time of $12 \mathrm{~min}$. A full loop injection mode was employed, with an injection volume of $10 \mu \mathrm{L}$. The mass spectrometer was operated in mode with electronspray-ionization (ESI) source. Operating conditions were optimized as follows: capillary voltage, $3.5 \mathrm{kV}$ (positive mode); ion source temperature, $120^{\circ} \mathrm{C}$; desolvation temperature, $450^{\circ} \mathrm{C}$; cone gas flow, $50 \mathrm{~L} / \mathrm{h}$; desolvation gas flow, $700 \mathrm{~L} / \mathrm{h}$ (nitrogen gas in both cases); and collision gas flow, $0.15 \mathrm{~mL} / \mathrm{min}$ (argon gas).

\section{Total DNA extraction}

Cultures for each strain were grown on Czapek Yeast Autolysate agar (CYA) [46] for seven days at $25^{\circ} \mathrm{C}$. Mycelial discs were subcultured into $150 \mathrm{~mL}$ of CYA liquid media and incubated for a further three days at $25^{\circ} \mathrm{C}$, with agitation at $120 \mathrm{rev} \mathrm{min}^{-1}$. Mycelia were harvested by washing under sterile distilled water, vacuum filtration and freeze drying. Genomic DNA was extracted from $50 \mathrm{mg}$ samples of macerated mycelia, as well as from naturally contaminated Brazil nut material, according to Raeder and Broda [48]. DNA was electrophoresed in $1 \%$ agarose gels at $5 \mathrm{~V} \mathrm{~cm}^{-1}$ in the presence of ethidium bromide $\left(1 \mu \mathrm{g} \mathrm{mL} \mathrm{m}^{-1}\right)$, with Low DNA Mass ladder $^{\ominus}$ (Invitrogen) employed for quantification under UV at $254 \mathrm{~nm}$. 


\section{Molecular-based identification}

For all the isolates characterized in this study, a fragment of each of the rDNA ITS1-5.8S-ITS2 region, the $\beta$-tubulin and calmodulin genes were amplified using the universal primers ITS5/ITS4 [49], T1/T22 [23], and cmd5/cmd6 [50], respectively. Each PCR reaction contained $10 \mathrm{ng}$ of template DNA, $0.4 \mu \mathrm{M}$ of each primer, $200 \mu \mathrm{M}$ dNTPs, $1.5 \mathrm{mM} \mathrm{MgCl}_{2}$, 1.0 U Taq DNA polymerase and $1 \times$ IB Taq polymerase buffer (Phoneutria, Belo Horizonte, MG, Brazil). Temperature cycling was conducted with the following program: denaturation at $95^{\circ} \mathrm{C}$ for $4 \mathrm{~min}, 30$ cycles of denaturation at $94^{\circ} \mathrm{C}$ for $1 \mathrm{~min}$, primer annealing at $50^{\circ} \mathrm{C}$ for $1 \mathrm{~min}$, and extension at $72^{\circ} \mathrm{C}$ for $1 \mathrm{~min}$, plus a final elongation period at $72^{\circ} \mathrm{C}$ for $5 \mathrm{~min}$. PCR products were purified using ExoSAP-IT $^{\circ}$ (USB, Cleveland, Ohio, USA) and forward and reverse- sequenced using the Big Dye ${ }^{\circ}$ Terminator v3.1 Cycle Sequencing kit (Applied Biosystems, Foster City, CA, USA). Products were run on an ABI 3700 DNA sequencer (Applied Biosystems, Foster City, CA, USA). Sequences were quality-edited and mounted into contigs using the program Sequencher, version 4.8 (Gene codes Corporation, Ann Arbor, MI USA). Strains were identified on the basis of sequence similarity using the program BLASTn [51], against both the NCBI nucleotide $\mathrm{nr}$ database and a local database of sequences for Aspergillus ex-type strains (Additional file 2).

Nucleotide sequences for unique haplotypes of each species were deposited in the NCBI database. Ribosomal DNA ITS1-5.8S-ITS2 sequences were deposited in Genbank with the accession numbers KJ634089, KJ634090, KJ634091, KJ634092 and KJ634093, $\beta$-tubulin gene sequences with accession numbers KJ634094, KJ634095, KJ634096 and KJ634097, and calmodulin gene sequences with accession numbers KJ634098 and KJ634099.

\section{mtDNA SSU rDNA characterization and primer design for the Genus}

Based upon sequence alignment using ClustalW [52] of representative mtDNA SSU rDNA sequences for Aspergillus species available at Genbank (http://www.ncbi.nlm. nih.gov/) (Additional file 3), specific primers for the genus ASP_GEN_MTSSU_F1 and ASP_GEN_MTSSU_R1 were designed using the software Primer3 [53]. In order to test primer specificity in silico, electronic PCR was conducted using the program primersearch, available through The European Molecular Biology Open Software Suite (EMBOSS). Based upon BLAST searches, the specific primers were tested against both the NCBI nucleotide database and a local database of mtDNA SSU rDNA gene sequences for fungi documented on Brazil nut [29,45], comprising members of the genera Aspergillus, Acremonium, Chaetomium, Cladosporium, Colletotrichum, Exophiala, Fusarium, Graphium, Hypocrea, Paecilomyces,
Penicillium, Phialophora, Phoma, Rhizopus and Trichoderma (Additional file 3).

Specificity of the primer pair was validated in PCR reactions against DNA from Aspergillus species and other fungal genera common on Brazil nut [29], namely A. flavus, A. nomius, A. tamarii, A. fumigatus, A. niger, Fusarium solani, Penicillium citrinum, Trichoderma harzianum, and Cladosporium cladosporioides. PCR reactions were conducted using $15 \mathrm{ng}$ of template fungal DNA together with $0.20 \mu \mathrm{M}$ of each primer, $0,2 \mu \mathrm{g} / \mu \mathrm{L}$ of bovine serum albumin (BSA), 1.0U Taq DNA polymerase (Phoneutria, Belo Horizonte, MG, Brazil) and 1× IB Taq polymerase buffer (Phoneutria, Belo Horizonte, MG, Brazil). Validation was also performed on total DNA samples extracted from naturally contaminated Brazil nut samples, with a detection limit assessed on diluted DNA. PCR thermocycling, product purification, sequencing and editing were as described earlier, with an annealing temperature of $60^{\circ} \mathrm{C}$. All experiments were conducted in duplicate, with a positive internal amplification control (IAC) present in each sample and a separate negative control lacking template DNA included with PCR amplifications. The specific PCR product amplified with primers ASP_GEN_MTSSU_F1 and ASP_GEN_MTSSU_R1 was firstly digested using the restriction enzyme SnaBI (New England BioLabs, Ipswich, MA, USA), and a 154 bp fragment containing the annealing site for primer ASP_GEN_MTSSU_F $F_{1}$ then cloned into the vector pGEMTeasy (Promega, Madison, WI, USA) according to standard protocols. Following cloning, a recombinant strain was stored as a glycerine culture at $-80^{\circ} \mathrm{C}$. Plasmid DNA was isolated and $10 \mathrm{pg}$ used as an IAC template in all PCR reactions, together with the pGEM ${ }^{\circ}$-T Easy-targeting reverse primer M13, annealing to position 176 on the $\mathrm{pGEM}^{\circ}-\mathrm{T}$ Easy plasmid vector DNA sequence.

\section{mtDNA SSU rDNA PCR RFLP analysis}

The potential of the mtDNA SSU rRNA gene amplicon for inter-specific differentiation was investigated based upon polymorphism in restriction sites. The target mtDNA sequence was analysed in each of the Aspergillus species available at Genbank, which included six Aspergillus species with complete mitochondrial genome sequences [54]. Restriction maps were generated for each species using the program Sequence Manipulation Suíte (http://www. bioinformatics.org/sms2/rest_map.html). Following identification of suitable restriction sites for differentiation, RFLP digestion of the specific mtDNA amplicons was then tested across the section Flavi species and additional Aspergillus species isolated from Brazil nut. Each digest reaction volume of $30 \mu \mathrm{L}$ contained $1 \mathrm{mg}$ of PCR product, $1 \times$ restriction enzyme buffer React 1 (Invitrogen, Carlsbad, CA, USA), and $1 \mathrm{U}$ of the selected restriction enzyme DraI (Invitrogen, Carlsbad, 
CA, USA). Following a two hour incubation period at $37^{\circ} \mathrm{C}$, digest fragments were electrophoresed in $1 \%$ agarose gels at $5 \mathrm{~V} \mathrm{~cm}^{-1}$ in the presence of ethidium bromide $\left(1 \mu \mathrm{g} \mathrm{mL}^{-1}\right)$, and visualized under $\mathrm{UV}$ at $254 \mathrm{~nm}$. The marker Low DNA Mass ladder (Invitrogen, Carlsbad, CA, USA) was included on gels for digest fragment size estimation.

\section{Additional files}

\section{Additional file 1: MtDNA SSU rRNA gene Dral restriction mapping data for Aspergillus species.}

Additional file 2: Ribosomal DNA ITS, beta-tubulin and calmodulin gene sequences deposited at Genbank for Aspergillus ex-type strains.

Additional file 3: MtDNA SSU rRNA gene sequences deposited at Genbank for fungi documented on Brazil nut.

\section{Competing interests}

The authors declare that they have no competing interests.

\section{Authors' contributions}

GEOM participated in DNA extraction, polyphasic identification, sequencing and analysis, primer development and validation and RFLP analysis. MLMS participated in mycotoxin determination. OFS participated in mycotoxin determination. JSAD participated in collection of contaminated Brazil nut and fungal isolation. LIBK participated in collection of contaminated Brazil nut and fungal isolation. REH participated in collection of contaminated Brazil nut and fungal isolation. RMLCM participated in collection of contaminated Brazil nut, fungal isolation and molecular-based identification. RCG participated in collection of contaminated Brazil nut and fungal isolation. VSA conceived the study, participated in collection of contaminated Brazil nut and fungal isolation. DMCB conceived the study, participated in collection of contaminated Brazil nut, fungal isolation and molecular-based identification. RNGM conceived the study, participated in DNA extraction, polyphasic identification, sequencing and analysis, primer development and validation, RFLP analysis and drafted the manuscript. All authors have contributed to, read and approved the final manuscript.

\section{Acknowledgements}

This work was funded by EMBRAPA (Project "Inovações tecnológicas para o controle da contaminação da castanha-do-Brasil por aflatoxinas") and CNPq (Project "Aspectos epidemiológicos e moleculares no diagnóstico e controle da contaminação da castanha-do-Brasil por aflatoxinas"). GEOM was supported by a fellowship from CAPES at Universidade de Brasília. RNGM was supported by a fellowship from CNPq. We thank anonymous reviewers for their useful comments on the manuscript.

\section{Author details}

'Departamento de Biologia Celular, Instituto de Ciências Biológicas, Universidade de Brasília, Campus Universitário Darcy Ribeiro, CEP 70.910-900 Brasília D.F., Brazil. ${ }^{2}$ EMBRAPA Centro Nacional de Pesquisa de Tecnologia Agroindustrial de Alimentos, Avenida das Americas, 29501, Guaratiba, CEP 23.020-470 Rio de Janeiro, RJ, Brazil. " ${ }^{3}$ EMBRAPA Amapa, Rodovia Juscelino Kubitschek, Km 5, No. 2600, CEP 68.903-419, Caixa Postal 10, Macapa, AP, Brazil. ${ }^{4}$ Instituto Nacional de Pesquisas da Amazônia, Avenida André Araújo, 2936, CEP 69.067-375, Caixa Postal 2223, Manaus, AM, Brazil. ${ }^{5}$ EMBRAPA Acre, BR 364, Km 14, Zona Rural, CEP 69.908.970, Caixa Postal 321, Rio Branco, AC, Brazil. 'EMBRAPA Amazônia Ocidental, Rodovia AM-010, Km 29, CEP 69.011-970, Caixa Postal 319, Manaus, AM, Brazil.

Received: 20 December 2013 Accepted: 23 May 2014

Published: 30 May 2014

\section{References}

1. JECFA. Joint Expert Committee on Food Additives: Evaluation of certain food additives and contaminants. Forty-sixth Report of the Joint FAOMHO Expert
Committee on Food Additives; 1996. WHO Technical Report Series 868. Geneva: World Health Organization; 1997.

2. Council For Agriculture Science And Technology (Cast: Mycotoxins: Risks in Plant, Animal and Human Systems. Ames, lowa: Council for Agricultural Science and Technology; 2003.

3. Holzapfel CW: The isolation and structure of cyclopiazonic acid, a toxic metabolite of Penicillium cyclopium Westling. Tetrahedron 1968, 24:2101-2119

4. Rao BL, Husain A: Presence of cyclopiazonic acid in kodo millet (Paspalum scrobiculation) causing "kodua poisoning" in man and its production by associated fungi. Mycopathologia 1985, 89:177-180.

5. Rodrigues $P$, Venâncio A, Kozakiewicz Z, Lima N: A polyphasic approach to the identification of aflatoxigenic and non-aflatoxigenic strains of Aspergillus section Flavi isolated from Portuguese almonds. Int J Food Micro 2009, 129:187-193.

6. Samson RA, Varga J: What is a species in Aspergillus? Med Mycol 2009, 47(Suppl 1):13-20.

7. Varga J, Frisvad JC, Samson RA: Two new aflatoxin producing species, and an overview of Aspergillus section Flavi. Stud Mycol 2011, 69:57-80.

8. Gonçalves SS, Stchigel AM, Cano JF, Godoy-Martinez PC, Colombo AL, Guarro J: Aspergillus novoparasiticus: a new clinical species of the section Flavi. Med Mycol 2012, 50:152-160.

9. Soares C, Rodrigue P, Peterson SW, Lima N, Venâncio A: Three new species of Aspergillus section Flavi isolated from almonds and maize in Portugal. Mycologia 2012, 104:682-697.

10. Taniwaki MH, Pitt Jl, lamanaka BT, Sartori D, Copetti MV, Balajee A, Fungaro $\mathrm{MH}$, Frisvad JC: Aspergillus bertholletius sp. nov. from Brazil nuts. PLoS One 2012, 7(8):e42480

11. Freitas-Silva O, Venancio A: Brazil nuts: Benefits and risks associated with the contamination by fungi and mycotoxins. Food Res Int 2011, 44:1434-1440

12. Reis TA, Oliveira TD, Baquião AC, Gonçalves SS, Zorzete $P$, Corrêa B: Mycobiota and mycotoxins in Brazil nut samples from different states of the Brazilian Amazon region. Int J Food Microbiol 2012, 159:61-68.

13. Olsen M, Johnson P, Moller T, Paladino R, Lindblad M: Aspergillus nomius, an important aflatoxin producer in Brazil nuts? World Mycotoxin J 2008, 1:123-126.

14. Baquião $A C$, Zorzete $P$, Reis TA, Assunção E, Vergueiro S, Correa B: Mycoflora and mycotoxins in field samples of Brazil nuts. Food Control 2012, 28:224-229.

15. Gonçalves JS, Ferracin LM, Vieira MLC, lamanaka BT, Taniwaki MH, Fungaro MHP: Molecular analysis of Aspergillus section Flavi isolated from Brazil nuts. World J Microb Biot 2012, 28:1817-1825.

16. Rodrigues P, Soares C, Kozakiewicz Z, Paterson R, Lima N, Venancio A: Identification and characterization of Aspergillus flavus and aflatoxins. In Communicating Current Research and Educational Topics and Trends in Applied Microbiology. Edited by Méndez-Villas A. Badajoz: Formatex; 2007:527-534.

17. El Khoury A, Atoui A, Rizk T, Lteif R, Kallassy M, Lebrihi A: Differentiation between Aspergillus flavus and Aspergillus parasiticus from Pure Culture and Aflatoxin-Contaminated Grapes Using PCR-RFLP Analysis of aflR-aflJ Intergenic Spacer. J Food Sci 2011, 76:M247-M253.

18. Montiel D, Dickinson MJ, Lee HA, Dyer PS, Jeenes DJ, Roberts IN, James S, Fuller $\sqcup$, Matsuchima K. Archer DB: Genetic differentiation of the Aspergillus section Flavi complex using AFLP fingerprints. Mycol Res 2003, 107:1427-1434.

19. Lee CZ, Liou GY, Yuan GF: Comparison of the aflR gene sequences of strains in Aspergillus section Flavi. Microbiology 2006, 152:161-170.

20. Hinrikson HP, Hurst SF, Lott TJ, Warnock DW, Morrison CJ: Assessment of ribosomal large-subunit D1-D2, internal transcribed spacer 1, and internal transcribed spacer 2 regions as targets for molecular identification of medically important Aspergillus species. J Clin Microbiol 2005, 43:2092-2103.

21. Samson RA, Hong SB, Frisvad JC: Old and new concepts of species differentiation in Aspergillus. Med Mycol 2006, 44:133-148.

22. Carbone I, Kohn LM: A method for designing primer sets for speciation studies in filamentous ascomycetes. Mycologia 1999, 91:553-556.

23. Glass NL, Donaldson GC: Development of primer sets designed for use with the PCR to amplify conserved genes from filamentous ascomycetes. Appl Environ Microbiol 1995, 61:1323-1330. 
24. Pildain MB, Frisvad JC, Vaamonde G, Cabral D, Varga J, Samson RA: Two novel aflatoxin-producing Aspergillus species from Argentinean peanuts. Int J Syst Evol Micr 2008, 58:725-735.

25. Godet M, Munaut F: Molecular strategy for identification in Aspergillus section Flavi. FEMS Microbiol Lett 2010, 304:157-168.

26. Shapira R, Paster N, Eyal O, Menasherov M, Mett A, Salomon R: Detection of aflatoxigenic molds in grains by PCR. Appl Environ Microbiol 1996, 62:3270-3273

27. Luo J, Taniwaki MH, lamanaka BT, Vogel RF, Niessen L: Application of loopmediated isothermal amplification assays for direct identification of pure cultures of Aspergillus flavus, A. nomius, and A. caelatus and for their rapid detection in shelled Brazil nuts. Int J Food Microbiol 2014, 172:5-12.

28. Codex, Codex Alimentarius: Hazard analysis and critical control point (HACCP) system and guidelines for its application. ANNEX to Recommended International Code of Practice/General Principles of Food Hygiene. CAC/RCP 1-1969, Rev 4. FAOMHO Codex Alimentarius Commission. Rome: Food and Agriculture Organization of the United Nations, World Health Organization; 2003.

29. Costa AKF, Freire FCO, Icaro GPV, Andrade JA, Mendes FNP: Fungos associados a Castanha-do-Brasil (Bertholleti excels Humb. \& Bompl) e o amendoim (Arachis hypogaea L.) comercializados em Fortaleza (Ceara). Rev Ciênc Agron 2009, 40:455-460.

30. Radstrom P, Lofstrom C, Lovenklev M, Knutsson R, Wolffs P: 2003. Strategies for overcoming PCR inhibition. In PCR Primer: A Laboratory Manual. 2nd edition. Edited by Diefenbach CW, Dveksler GS. Cold Spring Harbor, New York: Cold Spring Harbor Laboratory Press; 2003:149-161.

31. Ito Y, Peterson SW, Wicklow D, Goto T: Aspergillus pseudotamarii, a new aflatoxin producing species in Aspergillus section Flavi. Mycol Res 2001, 105:233-239.

32. Calderari TO, Lamanaka BT, Frisvad JC, Pitt Jl, Sartori D, Pereira JL, Fungaro $\mathrm{MH}$, Taniwaki MH: The biodiversity of Aspergillus section Flavi in brazil nuts: from rainforest to consumer. Int J Food Microbiol 2013, 160:267-272.

33. Dorner JW, Cole RJ, Diener UL: The relationship of Aspergillus flavus and Aspergillus parasiticus with reference to production of aflatoxins and cyclopiazonic acid. Mycopathologia 1984, 87:13-15.

34. Dorner JW: Production of cyclopiazonic acid by Aspergillus tamarii Kita. Appl Environ Microbiol 1983, 46:1435-1437.

35. Vinokurova NG, Ivanushkina NE, Khmel'nitskaia II, Arinbasarov MU: Synthesis of alpha-cyclopiazonic acid by fungi of the genus Aspergillus. Prikl Biokhim Mikrobiol 2007, 43:486-489.

36. FAO: Manual on the application of the HACCP system in mycotoxin prevention and control. FAO Food and Nutrition Paper 73; 2003. http://www.fao.org/ docrep/005/y1390e/y1390e00.htm [18/12/13].

37. Lima AM, Gonçalves EC, Andrade SS, Barbosa MSR, Barroso KFP, de Sousa $M B$, Borges L, Vieira JLF, Teixeira FM: Critical points of Brazil nuts: a beginning for food safety, quality control and Amazon sustainability. J Sci Food Agric 2012, 93:736-740.

38. Bruns TD, White TJ, Taylor JW: Fungal Molecular Systematics. Annu Rev Ecol Syst 1991, 22:525-564.

39. $\mathrm{Xu}$ J, Singh RS: The inheritance of organelle genes and genomes: patterns and mechanisms. Genome 2005, 48:951-958.

40. Quirk JT, Kupinski JM: Interspecific mitochondrial DNA restriction fragment length polymorphisms in Aspergillus section Flavi. Mycologia 2002, 94:1078-1086.

41. Juhász Á, Engi H, Pfeiffer I, Kucsera J, Vágvolgyi C, Hamari Z: Interpretation of mtDNA RFLP variability among Aspergillus tubingensis isolates. Antonie Van Leeuwenhoek 2007, 91:209-216.

42. Klich MA, Mullaney EJ: DNA restriction enzyme fragment polymorphism as a tool for rapid differentiation of Aspergillus flavus from Aspergillus oryzae. Exp Mycol 1987, 11:170-175.

43. Tominaga M, Lee $Y-H$, Hayashi R, Suzuki Y, Yamada O, Sakamoto K, Gotoh K, Akita O: Molecular analysis of an inactive aflatoxin biosynthesis gene cluster in Aspergillus oryzae RIB strains. Appl Environ Microbiol 2006, 72:484-490.

44. Yuan GF, Liu CS, Chen CC: Differentiation of Aspergillus parasiticus from Aspergillus sojae by random amplification of polymorphic DNA. Appl Environ Microbiol 1995, 61:2384-2387.

45. Freire FC, Kozakiewicz Z, Paterson RRM: Mycoflora and mycotoxins in Brazilian black pepper, white pepper and Brazil nuts. Mycopathologia 2000, 149:13-19.
46. Pitt Jl, Hocking AD: Fungi and Food Spoilage. 3rd edition. New York: Springer; 2009

47. Schmidt-Heydt M, Abdel-Hadi A, Magan N, Geisen R: Complex regulation of the aflatoxin biosynthesis gene cluster of Aspergillus flavus in relation to various combinations of water activity and temperature. Int J Food Microbiol 2009, 135:231-237.

48. Raeder U, Broda P: Rapid preparation of DNA from filamentous fungi. Lett Appl Microbiol 1985, 1:17-20.

49. White TJ, Bruns T, Lee S, Taylor J: Amplification and direct sequencing of fungal ribosomal RNA genes for phylogenetics. In PCR protocols: A Guide to Methods and Applications. Edited by Innis MA, Gelgard DH, Sninsky JJ, White TJ. New York: Academic Press; 1990:315-322.

50. Hong SB, Cho HS, Shin HD, Frisvad JC, Samson RA: Novel Neosartorya species isolated from soil in Korea. Int J Syst Evol Microbiol 2006, 56:477-486.

51. Altschul SF, Madden TL, Schaffer AA, Zhang J, Zhang Z, Miller W, Lipman DJ: Gapped BLAST and PSI-BLAST: a new generation of protein database search programs. Nucleic Acids Res 1997, 25:3389-3402.

52. Thompson JD, Higgins DG, Gibson TJ: CLUSTAL W: improving the sensitivity of progressive multiple sequence alignment through sequence weighting, position specific gap penalties and weight matrix choice. Nucleic Acids Res 1994, 22:4673-4680

53. Rozen S, Skaletsky HJ: Primer3 on the WWW for general users and for biologist programmers. In Bioinformatics Methods and Protocols; Methods in Molecular Biology. Edited by Krawetz S, Misener S. New Jersey: Humana Press; 2000:365-386.

54. Joardar V, Abrams NF, Hostetler J, Paukstelis PJ, Pakala S, Pakala SB, Zafar N, Abolude OO, Payne G, Andrianopoulos A, Denning DW, Nierman WC: Sequencing of mitochondrial genomes of nine Aspergillus and Penicillium species identifies mobile introns and accessory genes as main sources of genome size variability. BMC Genomics 2012, 13:698.

doi:10.1186/1471-2180-14-138

Cite this article as: Midorikawa et al:: Characterization of Aspergillus species on Brazil nut from the Brazilian Amazonian region and development of a PCR assay for identification at the genus level. BMC Microbiology 2014 14:138.

\section{Submit your next manuscript to BioMed Central and take full advantage of:}

- Convenient online submission

- Thorough peer review

- No space constraints or color figure charges

- Immediate publication on acceptance

- Inclusion in PubMed, CAS, Scopus and Google Scholar

- Research which is freely available for redistribution 